\title{
A Comparative Proteomic Analysis of Lipoprotein(a) and Low-Density Lipoproteins
}

Raphaelle Bourgeois, MSc ${ }^{1,2}$, Audrey Anne Després BSc ${ }^{1,2}$, Jakie Guertin BSc ${ }^{1,2}$, Nicolas Perrot, MSc $c^{1,2}$, Patricia Mitchell, PhD Clarisse Gotti, $\mathrm{MSc}^{3}$, Sylvie Bourassa, $\mathrm{PhD}^{3}$, Corey Scipione, $\mathrm{PhD}^{4}$, Michael Boffa, $\mathrm{PhD}^{4}$, Patrick Couture, MD, $\mathrm{PhD}^{2,5}$, Arnauld Droit, PhD ${ }^{3,5}$, Marlys L Koschinsky, PhD ${ }^{4}$, Patrick Mathieu, MD ${ }^{1,6}$, Benoit Arsenault, PhD ${ }^{1,2}$

1.Centre de recherche de l'Institut universitaire de cardiologie et de pneumologie de Québec, QC, Canada 2.Department of Medicine, Faculty of Medicine, Université Laval, Québec, QC, Canada; 3.Proteomics platform of the CHU de Québec, QC, Canada; 4.Robarts Research Institute, London, ON, Canada; 5.Centre de recherche du CHU de Québec, QC, Canada; 6.Department of Surgery, Faculty of Medicine, Université Laval, Québec, QC, Canada

Lipoprotein(a) (Lp[a]), which consists of a low-density lipoprotein $(\mathrm{LDL})$ bound to apolipoprotein (apo)(a) ${ }^{1}$, is a robust genetic risk factor for cardiovascular diseases ${ }^{2,3,4}$. Although both lipoproteins carry other proteins than apoB and apo(a), few studies performed hypothesis-free, direct comparisons of the proteome of $L p(a)$ and LDL. We aimed at comparing the $L p(a)$ and the $L D L$ proteomes in healthy individuals.
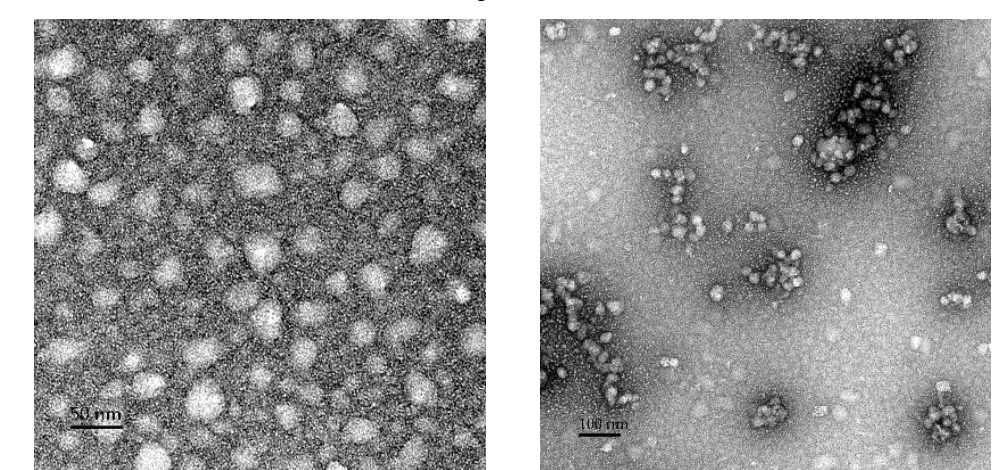

Figure 1: Electronic miscroscopy observation of isolated fractions of LDL (50K) and $\operatorname{Lp}(\mathrm{a})(25 \mathrm{~K})$

Methods and Results: We separated LDL from $L p(a)$ in the plasma of 6 healthy volunteers with $L p(a)$ levels $\geq 125 \mathrm{nmol} / \mathrm{L}$ using a combination of ultracentrifugation and fast protein liquid chromatography and performed a semi-quantitative assessment of the proteome of these lipoproteins using a label-free nanoLCMS/MS approach. We repeated these experiments in a replication phase that included 9 individuals, also with $\operatorname{Lp}(\mathrm{a})$ levels $\geq 125 \mathrm{nmol} / \mathrm{L}$. In the discovery phase, we identified 9 proteins that were more abundant on LDL compared to $L p(a)$ and 31 proteins that were more abundant on $\mathrm{Lp}(\mathrm{a})$ compared to LDL. None of the LDL proteins replicated while 15 proteins were found to be more abundant on $L p(a)$ compared to LDL in both phases following multiple testing adjustment. These proteins were also not detected on the LDL of individuals with low $L p(a)$ levels. Finally, quantitative analysis revealed that PCSK9 was detectable in $L p(a)$ subfractions and undetectable in LDL.

\section{Conclusions:}

- 15 proteins identified as preferencially associated with $L p(a)$. Lp(a) proteome seems to be more abundant than LDL proteome.

No proteins redistribution when little or no $L p(a)$.

These differences could explain the inflamatory and atherogenic caracteristics of $L p(a)$ and improve the comprehension of subsequent pro-inflamatory mechanisms.

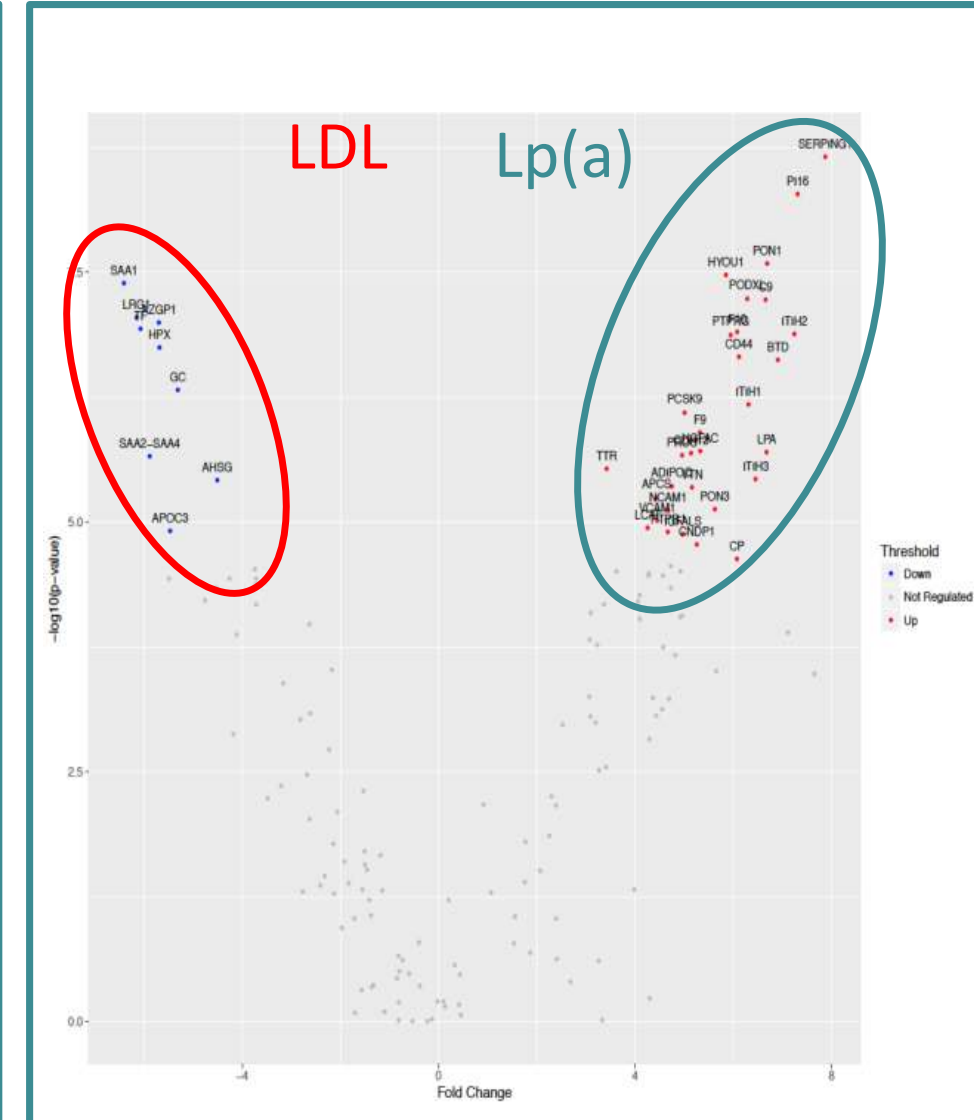

Figure 2: Volcano plot of proteins identified as preferentially enriched in $L D L$ and $L p(a)$ in the discovery phase

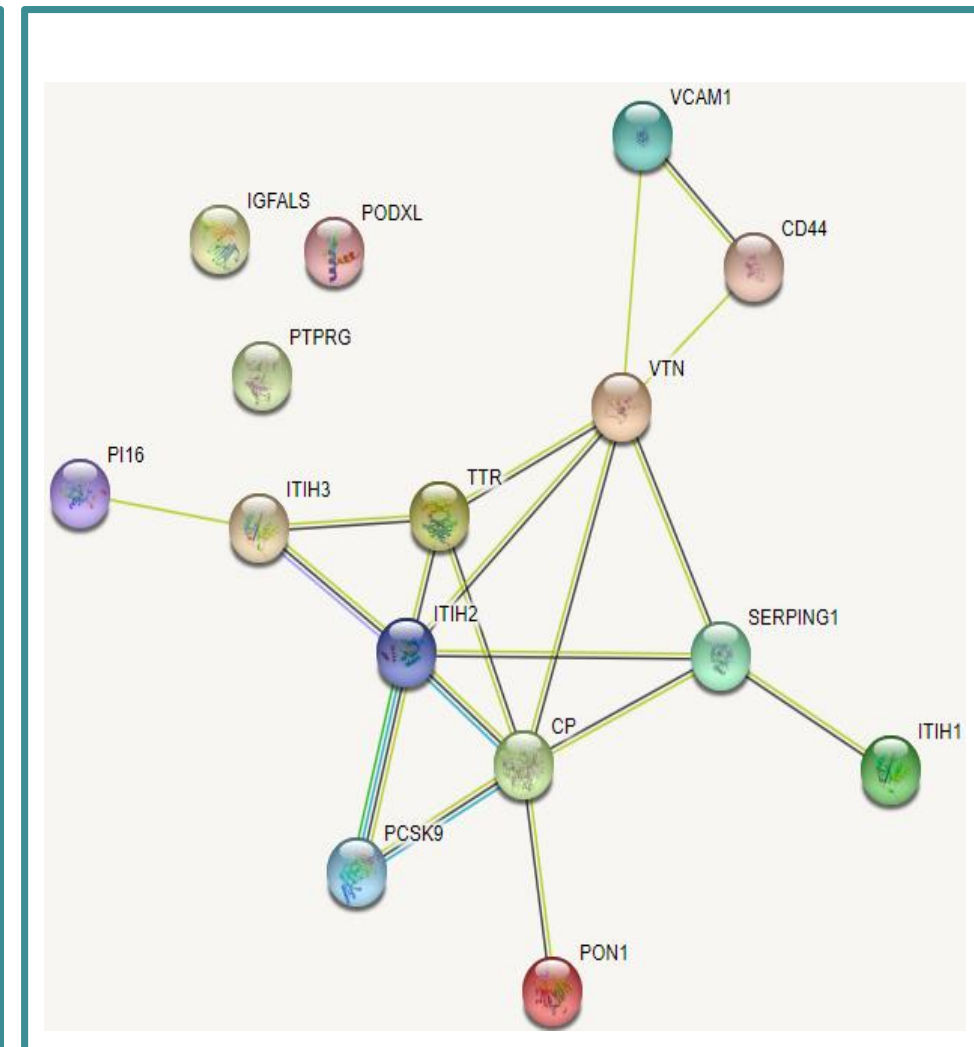

Figure 3 : Metabolic pathways analysis between Lp(a) enriched proteins by Sting $d b$

Table 1 : List of $L p(a)$ enriched proteins identified in discovery and replication phases

\begin{tabular}{|c|c|c|c|c|c|}
\hline \multirow[b]{2}{*}{ Gene } & \multirow[b]{2}{*}{ Protein } & \multicolumn{2}{|c|}{ Discovery phase } & \multicolumn{2}{|c|}{ Replication phase } \\
\hline & & $\begin{array}{l}\mathrm{Lp}(\mathrm{a}) / \\
\mathrm{LDL} \\
\text { ratio }\end{array}$ & $P$ value & $\begin{array}{l}\mathrm{Lp}(\mathrm{a}) / \\
\mathrm{LDL} \\
\text { ratio }\end{array}$ & $P$ value \\
\hline $\begin{array}{l}\text { SERPIN } \\
\text { G1 }\end{array}$ & Plasma protease $\mathrm{C} 1$ inhibitor & 234.8 & $2.19 \times 10^{-9}$ & 108.1 & $1.65 \times 10^{-5}$ \\
\hline Pl16 & Peptidase inhibitor 16 & 158.8 & $5.19 \times 10^{-9}$ & 17.2 & 0.02 \\
\hline ITIH2 & $\begin{array}{l}\text { Inter-alpha-trypsin inhibitor } \\
\text { heavy chain } \mathrm{H} 2\end{array}$ & 151.5 & $1.30 \times 10^{-7}$ & 17.8 & $1.14 \times 10^{-5}$ \\
\hline PON1 & $\begin{array}{c}\text { Serum } \\
\text { paraoxonase/arylesterase } 1\end{array}$ & 103.4 & $2.59 \times 10^{-8}$ & 35.0 & $2.39 \times 10^{-6}$ \\
\hline $\mathrm{ITIH} 3$ & $\begin{array}{l}\text { Inter-alpha-trypsin inhibitor } \\
\text { heavy chain } \mathrm{H} 3\end{array}$ & 87.8 & $3.69 \times 10^{-6}$ & 30.2 & $9.39 \times 10^{-4}$ \\
\hline $\mathrm{ITIH} 1$ & $\begin{array}{l}\text { Inter-alpha-trypsin inhibitor } \\
\text { heavy chain } \mathrm{H} 1\end{array}$ & 79.3 & $6.57 \times 10^{-7}$ & 16.0 & $2.74 \times 10^{-5}$ \\
\hline PODXL & Podocalyxin & 77.9 & $5.74 \times 10^{-8}$ & 150.9 & $6.53 \times 10^{-10}$ \\
\hline CD44 & CD44 antigen & 69.3 & $2.22 \times 10^{-7}$ & 253.0 & $5.80 \times 10^{-11}$ \\
\hline $\mathrm{CP}$ & Ceruloplasmin & 67.5 & $2.31 \times 10^{-5}$ & 614.7 & $1.16 \times 10^{-5}$ \\
\hline PTPRG & $\begin{array}{l}\text { Receptor-type tyrosine- } \\
\text { protein phosphatase gamma }\end{array}$ & 61.8 & $1.32 \times 10^{-7}$ & 62.1 & $1.40 \times 10^{-8}$ \\
\hline VTN & Vitronectin & 35.7 & $4.50 \times 10^{-6}$ & 9.8 & $6.71 \times 10^{-6}$ \\
\hline PCSK9 & $\begin{array}{l}\text { Proprotein convertase } \\
\text { subtilisin/kexin type } 9\end{array}$ & 32.3 & $7.94 \times 10^{-7}$ & 6.7 & $1.66 \times 10^{-2}$ \\
\hline IGFALS & $\begin{array}{l}\text { Insulin-like growth factor- } \\
\text { binding protein complex acid } \\
\text { labile subunit }\end{array}$ & 31.4 & $1.31 \times 10^{-5}$ & 6.5 & $2.93 \times 10^{-5}$ \\
\hline VCAM1 & $\begin{array}{l}\text { Vascular cell adhesion } \\
\text { protein } 1\end{array}$ & 21.9 & $9.62 \times 10^{-6}$ & 5.0 & $1.61 \times 10^{-2}$ \\
\hline TTR & Transthyretin & 10.7 & $2.89 \times 10^{-6}$ & 16.2 & $1.89 \times 10^{-7}$ \\
\hline
\end{tabular}

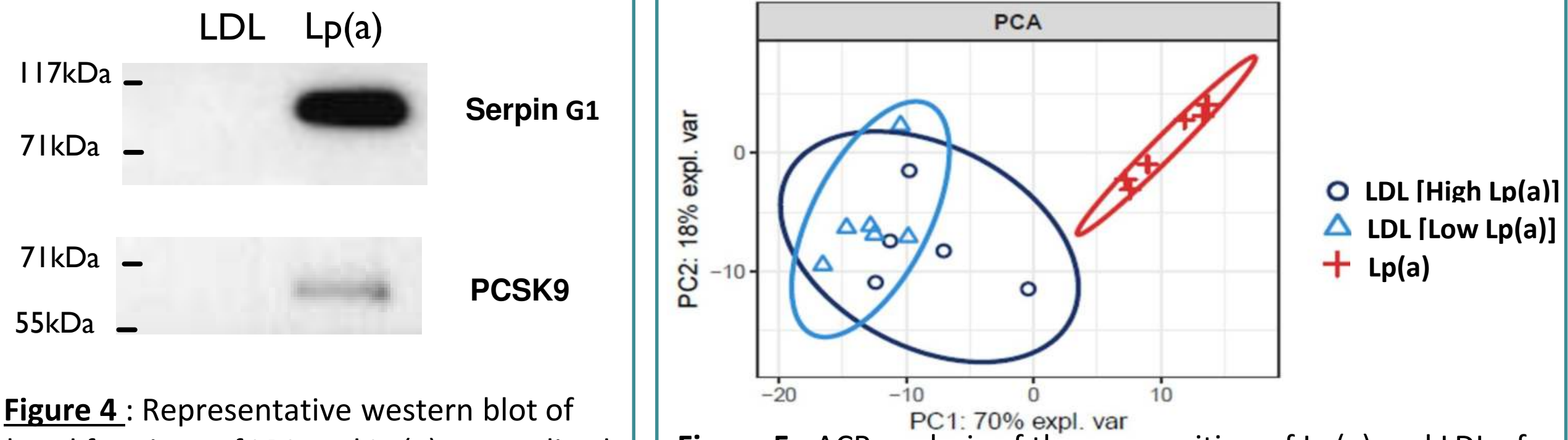

isolated fractions of $L D L$ and $L P(a)$, normalized by cholesterol $(n=4)$
Figure 5 : ACP analysis of the composition of $L p(a)$ and $L D L$ of subjects with high vs low $\mathrm{Lp}(\mathrm{a})$

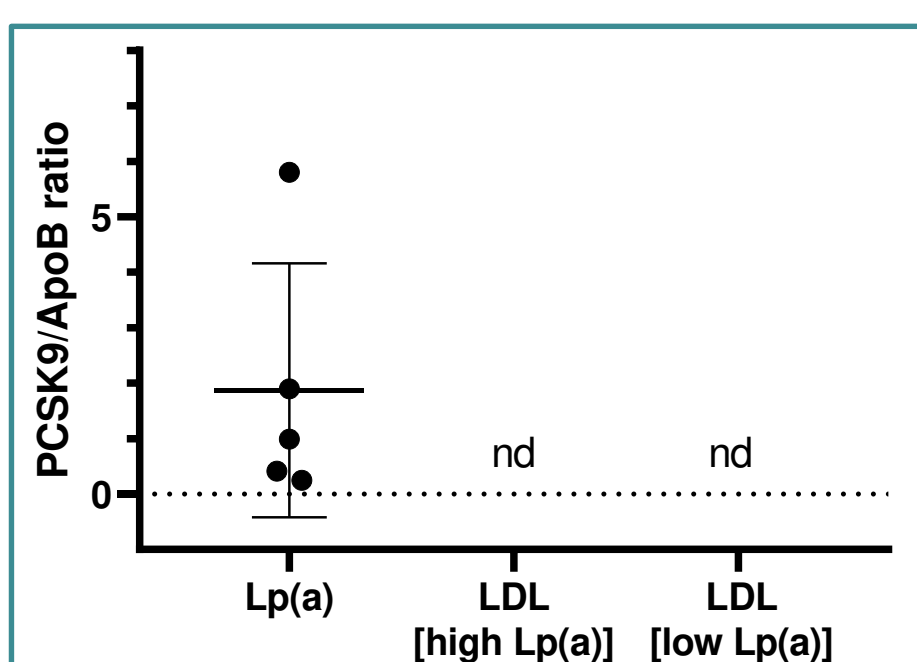

Figure 6: PRM analysis of PCSK9 and $A p o B$ in $L p(a)$ and LDL of subjects with high vs low $L p(a)$ 